\title{
USGS Western Coastal and Marine Geology Team
}

he Western Coastal and Marine
Geology Team of the U.S.
Geological Survey (USGS) studies the
coasts of the western United States,
including Alaska and Hawai i. Team
scientists conduct research, monitor
processes, and develop information
about coastal and marine geologic
hazards, environmental conditions,
habitats, and energy and mineral
resources. This information helps
managers at all levels of government
and in the private sector make
informed decisions about the use and
protection of national coastal and
marine resources.

\section{Locations and Personnel}

The Western Coastal and Marine Geology Team consists of about 120 people located in Santa Cruz and Menlo Park, California. Work and staff are integrated with the other U.S. Geological Survey (USGS) Coastal and Marine Geology centers in Woods Hole, Massachusetts, and St. Petersburg, Florida.

\section{Examples of Current Research}

Coastal Erosion.-Sea-cliff collapse and loss of beach sand are among the coastal-

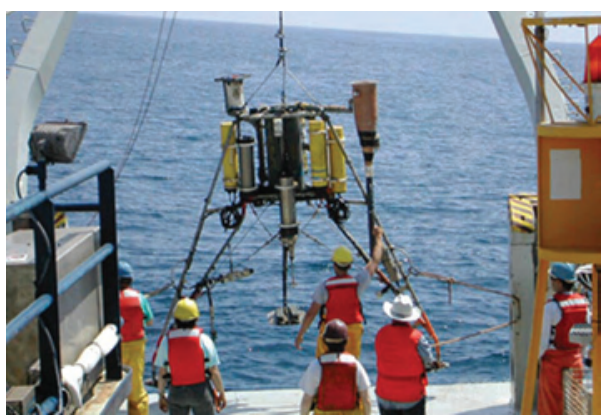

Scientists recover an instrumented tripod that spent several weeks on the sea floor off southern California, recording data on currents, suspended sediment concentrations, and other parameters related to sediment and pollutant transport.

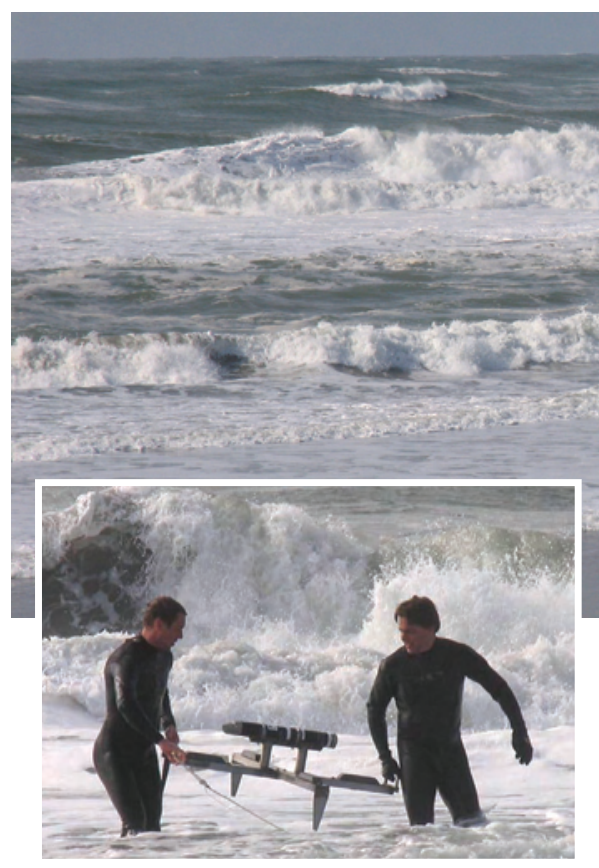

erosion problems being studied by team scientists. Field measurements-including repeated high-resolution lidar (light detection and ranging) surveys of coastal cliffs, surfzone current measurements, and detailed mapping of beach topography and nearshore bathymetry-are combined with conceptual and numerical models in order to quantify short- and long-term coastal changes, develop predictive models, and assist regional coastal-zone and sediment management. Partners include local, State, and Federal agencies and academic institutions.

Tsunami Hazards.-USGS researchers are working with the National Oceanic and Atmospheric Administration (NOAA) and other agencies to identify places where tsunamis might be triggered, including offshore fault zones and areas prone to submarine landslides. USGS staff have had a prominent role in documenting the geologic impacts of recent tsunamis, including the tragic 2004 Indian Ocean tsunami. This documentation is being used to improve interpretation of ancient tsunami deposits and to aid in developing local and national tsunami-hazard assessments.
Andrew Schwartz and Dan Hanes maneuver a current profiler for a study of surf-zone hydrodynamics at Ocean Beach, on the west side of San Francisco, California. Beach erosion has been a continuing problem in this area, and this fieldwork is part of an effort to document analyze, and simulate the processes that control sand transport and sedimentation patterns.

California Urban Ocean.-Team scientists are studying the processes that control the distribution of sediment and pollutants "from source to sink" in coastal environments offshore large population centers in southern and central California. Federal, State, and local agencies help support this work, which includes documenting and modeling processes that transport sediment

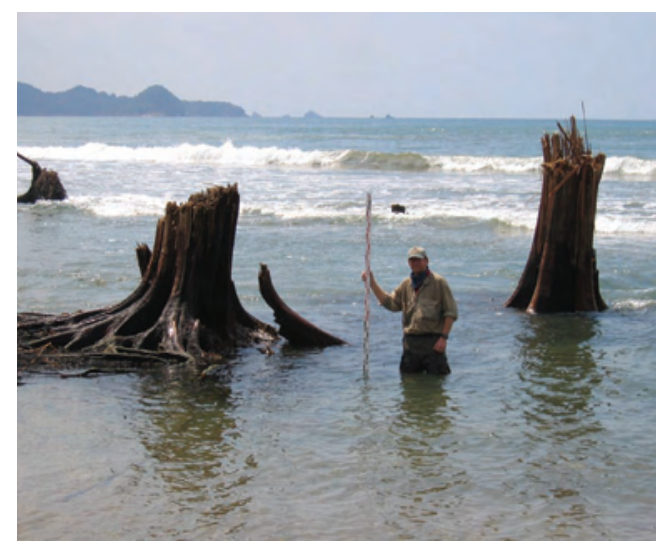

Guy Gelfenbaum measures coastal subsidence along Sumatra's northwest coast caused by the December 2004 earthquake that triggered a devastating tsunami in the Indian Ocean. Submergence of the tree roots indicates that the land here subsided 1 to 2 meters during the earthquake; the trees were snapped off by the tsunami. 
and pollutants and mapping the distribution of sediments and pollutants.

Puget Sound Nearshore Project.-Urbanization around Puget Sound, Washington, has caused declines in fish and wildlife, water quality, and ecosystem health. As part of the Puget Sound Nearshore Ecosystem Restoration Project-a cooperative effort involving Federal, State, and local agencies-USGS scientists are developing information on the sound's physical, chemical, and biological processes. Work focuses on the effects of urbanization on nearshore ecosystems, the restoration of large river deltas, and the ecosystem impacts of dam removal (see below).

Earthquake Hazards.-The USGS is mapping the locations, geometry, slip rates, and earthquake-recurrence intervals of active faults offshore California and the Pacific Northwest - information essential for seismichazard assessment and mitigation. In selected coastal zones, the USGS is also mapping soil and rock properties that affect earthquakeinduced ground motions in order to assess the potential for liquefaction and landslides.

Offshore Geologic Mapping._-USGS scientists combine high-resolution bathymetry with underwater video and sea-floor sampling to develop offshore geologic

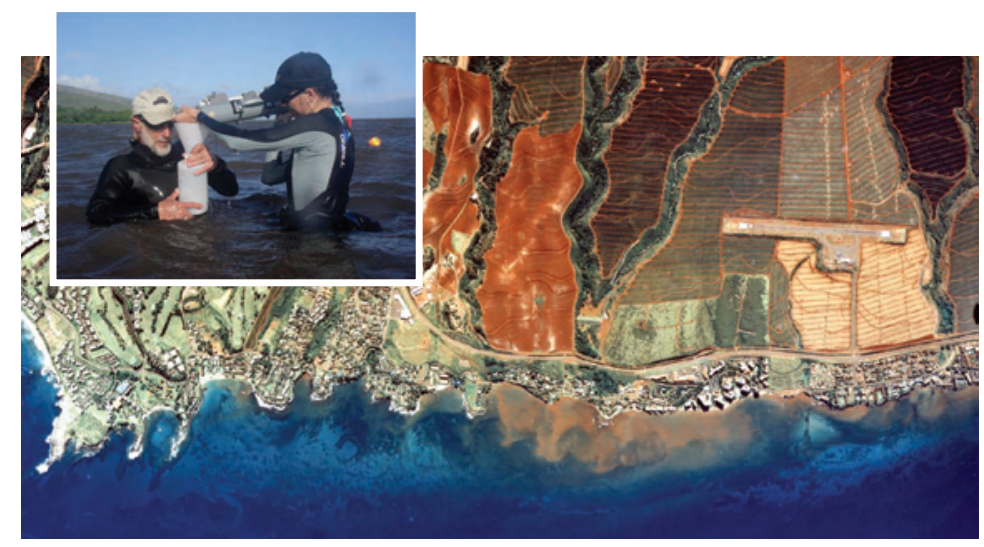

Land-derived sediment (brown) drifts over coral reefs off the Island of Maui, Hawai i. USGS scientists are studying the effects of sediment and pollutants on coral-reef health. Inset: Mike Torresan and Charlene Tetlak Parsons collect water sample for analysis of suspended sediment.

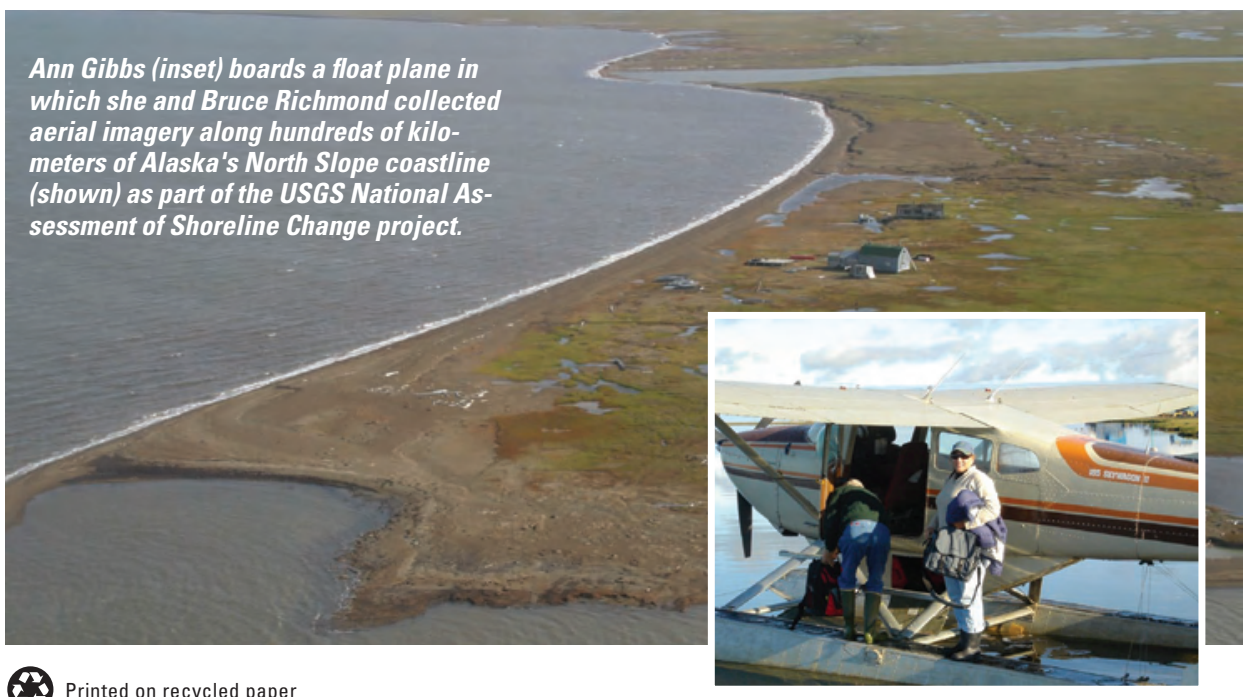

Coral Reefs._-USGS scientists are mapping the distribution and condition of coral reefs as part of a national effort to understand and protect these fragile environments. A special focus is on the influence of land-derived sediments and contaminants on reef health. Projects are underway in Hawai'i and Guam in cooperation with the National Park Service, the University of Hawai i, and others.

Dam Removal.-Thousands of small dams in the United States will be removed during the 21 st century, owing to their age or to ecosystem-restoration efforts. USGS scientists are collecting baseline data and preparing to document the effects on local habitats and water quality of sediment released by the removal of dams in Washington and California.

Knowledge Management.-Team members are developing tools for processing, distributing, and archiving large volumes of coastal and marine data. These tools include data-management guidelines; a team Web site and field-data catalog (http://walrus. wr.usgs.gov/infobank/); a monthly USGSwide newsletter (Sound Waves, http://sound waves.usgs.gov); and the National Archive of Marine Seismic Surveys (http://walrus. wr.usgs.gov/NAMSS).

These varied research endeavors of the USGS Western Coastal and Marine Geology Team, in cooperation with other organizations, provide information essential to sound management of the Nation's western coasts and seas.

Sam Johnson, Helen Gibbons

Edited by Peter H. Stauffer Graphic design by Judy Weathers

For more information contact: Samuel Y. Johnson, Chief Scientist USGS Pacific Science Center 400 Natural Bridges Drive

Santa Cruz, CA 95060 (831) 427-4746

sjohnson@usgs.gov

http://walrus.wr.usgs.gov/

This fact sheet and any updates to it are available online at http://pubs.usgs.gov/fs/2007/3050 